\title{
COMPARISON OF TOTAL COST OF PRODUCTION AND TOTAL REVENUE BETWEEN DROUGHT TOLERANT AND OTHER CULTIVATED RICE VARIETIES IN TANAHUN, NEPAL
}

\author{
${ }^{1}$ Sandesh Acharya, ${ }^{1}$ Prayash Pathak Chalise, ${ }^{2}$ Niroj Dahal \\ ${ }^{1}$ Institute of Agriculture and Animal Science, Tribhuwan University, Kathmandu, Nepal \\ ${ }^{2}$ Maya Institute of Agriculture and Technology, Dehradun, India
}

DOI: 10.46609/IJSSER.2020.v05i08.011 URL: https://doi.org/10.46609/IJSSER.2020.v05i08.011

\begin{abstract}
Rice production is greatly influenced by drought that results low and varied productivity of rice. Considering the importance of rice production in the national economy, this study aims to assess situation, socio-economics, and productivity of different rice varieties in Tanahun district. Randomly selected 40 paddy growing farmers from different locations were the primary informants. Data was collected in semi structured questionnaire through interview in local language and was analyzed using MS Excel and SPSS. The B:C ratio observed from the study was $1.157,1.236,1.109,1.125,1.162,0.974,1.249$ and 1.074 for sukhkha2, sukhkha3, sukhkha4, sukhkha5, sukhkha6, local varieties, other improved and hybrid varieties respectively. The total cost of production in NRs per hectare was 179340, 179900, 188040, 203200, 169050, 185728,185720 and 205280 respectively. Similarly the productivity in ton/ha was 4.21, 4.53, $4.15,4.75,3.75,3.68,4.73$ and 4.55 respectively for each variety. Maximum revenue was obtained from sukhkha5. This study concludes that those drought tolerant rice varieties especially sukhkha5 (when sown in rainfed upland area) gives better results than hybrid and other improved varieties in terms of productivity and total revenue but, other improved varieties and sukhkha3 are more economic when $\mathrm{B}: \mathrm{C}$ ratio is considered. This research strongly recommends providing specific cultivation guidelines and labor efficient methods for cultivation of Sukhkha3 and Sukhkha5 to farmers through extension demonstration and awareness creation. Further identification and mapping of other drought-prone domains for further dissemination ensures the drought security in the country.
\end{abstract}

Keywords: Drought tolerant, Productivity, B: C Ratio, Food insecurity, Mapping 


\section{International Journal of Social Science and Economic Research}

ISSN: $2455-8834$

Volume:05, Issue:08 "August 2020"

\section{INTRODUCTION}

\subsection{Background}

As rice is the most staple food of Asia, More than $90 \%$ of the rice is produced and consumed in Asia, where $60 \%$ of the world population lives and it covers about $10 \%$ of the world's arable land (FAO, 2002). In Asia, 17 million ha of irrigated rice area may experience "physical water scarcity" and 22 million ha may have "economic water scarcity"by 2025 (Tuong and Bauman, 2001). Nepal's economy is more affected by climatic stress such as drought flooding and other natural disasters than any other hazards. Two-third of rice area in Nepal is rainfed and most of them are stress-prone (drought and flood prone) where, low production and high variability occur in rice production due to uncertain weather conditions resulting from drought and/ or flooding during monsoon season (Gauchan et al, 2012).

Efforts were made by International Rice Research institute (IRRI) and National Rice Research Program (NRRP) Hardinath to manage rainfed lowland rice cultivation with drought-tolerant varieties in Nepal. Newly developed drought-tolerant rice varieties viz; Sukhadhan 1, 2, 3 ,4 5, and 6 have shown new hope for farmers in drought-prone areas which is nearly $30 \%$ of the total rice cultivated areas in the country. These varieties have shown great promise in reducing poverty and vulnerability of the people in drought and flood prone areas of South and South East Asia (Pandey et al, 2010; Mackill, 2011).Environmental, biological, socio-cultural,economic and policy factors influence a farmer's decision to select and replace or maintain a particular variety at any given time (Jarvis et al., 2000)Environmental, biological, socio-cultural, economic and policy factors influence a farmer's decision to select and replace or maintain a particular variety at any given time (Jarvis et al., 2000).

When rainfall water infiltrates and retained in the soil, it increases the rate of available soil moisture for crops growth and development (Kajiru, 2006). Saito et al. (2005) revealed that there is a yield increase of upland rice improved varieties when water stress does not exist during the growth stage.

\subsection{Statement of problems}

The semi-aquatic nature of rice and high water requirements for its cultivation make it much more prone to losses from drought than other cereals. As a result of the reduction in water availability and recent climate change scenarios, rice production is likely to be more severely affected by drought in hilly areas of Nepal. In Nepal, 30\% and $15 \%$ of total rice cultivated areas are prone to drought and submergence respectively (Gumma et al 2011). Globally, extreme poverty and food insecurity continues to be a rural phenomenon (Anriquez and Stamoulis 2007). The incidence of poverty in Nepal is higher in the Hills and Mountains than in the plain region or 


\section{International Journal of Social Science and Economic Research}

ISSN: $2455-8834$

Volume:05, Issue:08 "August 2020"

Terai (NLSS, 2004). People in mountainous areas tend to be poorer and more food insecure than in comparable flat areas (Templetion and sherr 1999).

The main factors responsible for low upland and lowland rice yield are inadequate supply of various essential inputs like quality fertilizer, improved seed and pesticides, coupled with lack of adequate irrigation facility and knowledge on improved techniques of cultivation.

In addition, the poor farming techniques, insufficient incentive to augment production under the traditional system of land tenure, and lack of agricultural credit and marketing facilities in the study area are the factors responsible for low agricultural production and benifits. Particularly in the case of rice cultivation; drought, credit supply, input supply, soil problem, weeds, pests and diseases are recognized as the major production problems in Nepal (Television Trust for Environment, 2004).

\subsection{Rationale of study}

Considering the importance of rice production in the national economy and the problems faced by farmers, this study aims to assess situation, economics, potentials and constraints of rice production. One of the important ways to ensure food security and at the same time provide viable incomes for poor rice farmers in the future is to develop new rice varieties that are more tolerant of the adverse effects of a more volatile climate (Mackill et al., 2010a; Haefele et al., 2010). These newer rice varieties can help minimize production losses from the expected increase in abiotic and biotic stresses due to climate change, can maintain normal productivity, ensure food security and uplifts the economic condition of the farmers.

\subsection{Hypothesis Testing}

The research will begin by testing whether the recommended varieties perform as expected and found socioeconomically feasible and preferable using the following hypothesis;

Null hypothesis; Sukha varieties showed good performance in Tanahun.

Alternate hypothesis; Sukha varieties did not show good performance in Tanahun.

\subsection{Objectives}

1. To determine total production costs, physical productivity, total revenue and gross margin of sukhkha, local, improved and hybrid rice in the study area.

2. To find out socioeconomic factors of Sukhkha, local, improved and hybrid rice growers in Tanahun District of Nepal. 
International Journal of Social Science and Economic Research

ISSN: 2455-8834

Volume:05, Issue:08 "August 2020"

3. To compare B:C Ratio and Net profit of different rice varieties.

4. To know which variety is most preferred by farmers while eating. This study also aims to find the cause of preference/ reasons for its preference.

\section{MATERIALS AND METHODS}

\subsection{Study area:}

The research work was conducted in 40 households of Tanahun district of Nepal in January to February, 2018. Tanahun district lies in the geographical coordinates of $27.9447^{\circ} \mathrm{N}$ and $84.2279^{\circ}$ E. The selection of growers has been carried out based on the criteria of adopter and non-adopter of Sukhkha rice. Primary data was collected from sample of 40 rice growers from different places like Rupakot, Purkot, Bhanu, Bandipur and Anbukhaireni.

\subsection{Research design:}

The study was mainly based on primary information collection from rice farmers of Dudhikuna, MirlungBhanghyang, Ratanpur, Chudi, Satrasaya, khairenitar, chambas and Bandipur. These places were purposively selected for the study due to availability of drought tolerant rice growing farmers. Sampling frame was prepared from key informant's interview in each location. This study used survey research design in order to collect information from respondents.

\subsection{Data collection:}

Information about Rice production and other necessary aspects was collected variety and operation wise, by employing comprehensive and pre tested questionnaire. In order to enhance the response rate, data was collected through interview .Although questionnaire was prepared in English language while the interview with respondents was done in local language i.e. Nepali. Different features were covered in the questionnaire. Missing information required was obtained from telephone conversation with the respective farmers.

\subsection{Questionnaire development:}

In all statistical surveys questionnaires are considered as the medium for recording the information obtained in a standardized manner. Keeping in view the comparative analysis of the economics of Sukhkha, Local, other improved and Hybrid Rice production, semi structured questionnaire was developed; Questionnaire included important questions to obtain information about comparative all rice varieties production along with other socio-economic characteristics of the farm house hold. 
International Journal of Social Science and Economic Research

ISSN: 2455-8834

Volume:05, Issue:08 "August 2020"

\subsection{Data collection procedure:}

Randomly selected paddy growing farmers from each location were the primary informants. Total 40 household surveys were taken from different places :Dudhikuna, MirlungBhanghyang, Ratanpur, Chudi, Chirkane, khairenitar, chambas and Bandipur. 5 farmers who are mostly sukhkha rice producing were selected from each location. The information about sukhkha rice farmers were obtained from key informants in each location.

\subsection{Pre-testing of questionnaire}

The questionnaire was pre-tested prior to administrating to actual respondents for checking the reliability and validity of questions. The pre-testing was done on 5 households of Bhanu Municipality and correction was made in finalized questionnaire.

\subsection{Data analysis:}

After completing the field work, the data were edited and transferred from the questionnaires into worksheet as a database file (SPSS). The variable names within the database file refer to the numbers of each question in the questionnaire; to compare the productivity of Sukhkha, local, improved and hybrid varieties through production cost analysis, total revenue, gross margin, benefit -cost ratio and productivity analysis. Results were presented in charts, figures, and tables. Interpretations were made on the basis of results, which were assisted by qualitative and quantitative data available from primary and secondary survey.

\subsection{Descriptive analysis}

The descriptive analysis was used to describe the socio demographic characterstics of drought tolerant and other paddy growing farmers. Different variables like family size, age of $\mathrm{HH}$, education, occupation and ethnicity of $\mathrm{HH}$ were analyzed by descriptive statistical tools such as frequencies, percentage, mean were applicable.

\section{Farm cost Analysis}

The farm cost analysis is based on Sukhkha, local, improved and hybrid rice production. The results of this study will provide for the comparison of total costs and returns Rice varieties. Total costs consist of expenditure from the profit and loss account (fixed costs and variable costs etc.). For the estimation and calculations, following procedure is adopted to examine the profitability of different varieties of Rice: 


\section{International Journal of Social Science and Economic Research}

Total revenue: Total revenue is the total money received from the sale of any given quantity of output. The total revenue is calculated by taking the price of the sale times the quantity sold.

Total revenue $=$ price $\mathrm{x}$ physical productivity

Total costs: Total Cost is the sum of the fixed cost and total variable cost for any given level of production.

Total Cost fixed cost + total variable cost

Total fixed costs: Total fixed costs are the costs that do not change with the level of production. For example, water Charges, Govt. Land Taxes.

Total variable costs: Total variable costs are the costs that change in direct proportion to changes in volume

Profit: Profit is the excess of receipts over the spending of business during any period

Profit $=$ gross income - expenses

Gross margin: A gross margin is calculated by taking variable costs away from the gross income earned from an enterprise.

Gross margins are often reported on a per rupees basis for cropping enterprises.

Gross margin $=$ returns - variable costs.

B: C Ratio: Benefit Cost Ratios of different rice varieties has been calculated for finding the most profitable rice variety in terms of total and net revenue. More specifically the Benefit Cost Ratio (BCR) for each variety was:

$\mathrm{BCR}=\mathrm{VNR} / \mathrm{TC}$

Where,

$\mathrm{VNR}=$ Variety net revenue and

$\mathrm{TC}=$ Total cost of production of the variety

More and more the value of Benefit Cost Ratio more will be the net return.

Productivity: Productivity (ton/ha): rice yield (kg) in 1 ropani*20/1000 


\section{RESULT AND DISCUSSION}

\subsubsection{Demographic and socio-economics of sampled farmers:}

The socio-economic characteristics of the households include age distribution, population and sex distribution, economically active population, education, ethnicity and occupation.

Demography:

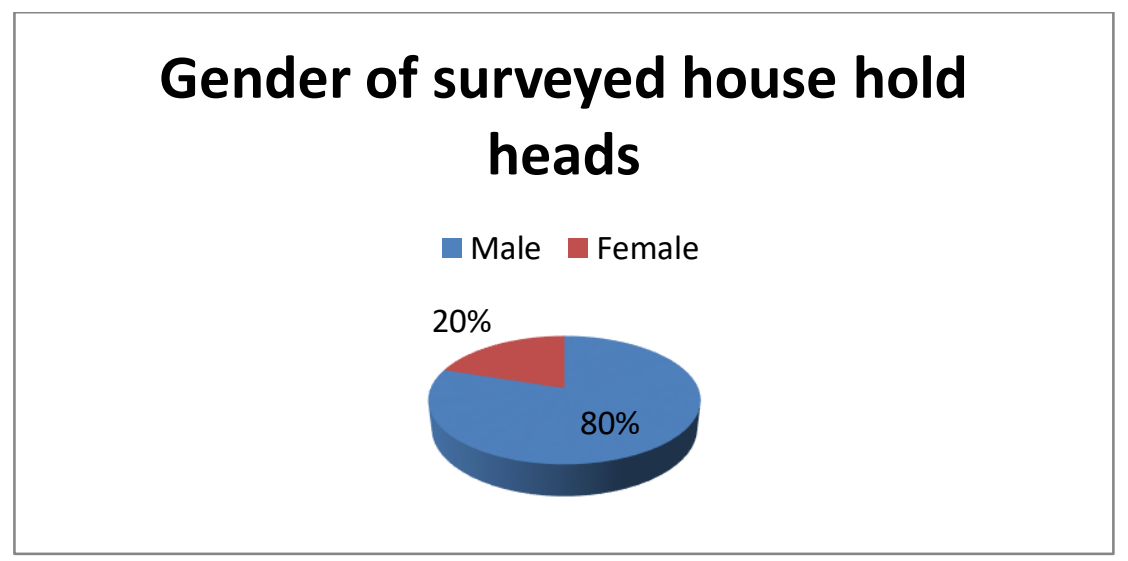

\subsubsection{Ethnicity}

The distribution of the population by ethnicity revealed that majority of the population residing in tanahun district constituted Bramhin/Chettri 57.5\%, followed by Adibasi/Janajati 20\%. Dalit constituted $15 \%$ and other caste were $7.5 \%$ of the sampled population.

\subsubsection{Land distribution}

In this study, 17.1 ha of land was surveyed which comprises $48.2 \%$ upland and $51.8 \%$ lowland area. The average land holding was observed to be 8.55 Ropani (i.e 0.4274 ha). Upland rice was cultivated in $22.84 \%$ of the total area, lowland paddy in $35.07 \%$, and $42.09 \%$ of the total land was rice uncultivated land used for other purposes like housing, growing other crops etc. 
International Journal of Social Science and Economic Research

ISSN: 2455-8834

Volume:05, Issue:08 "August 2020"

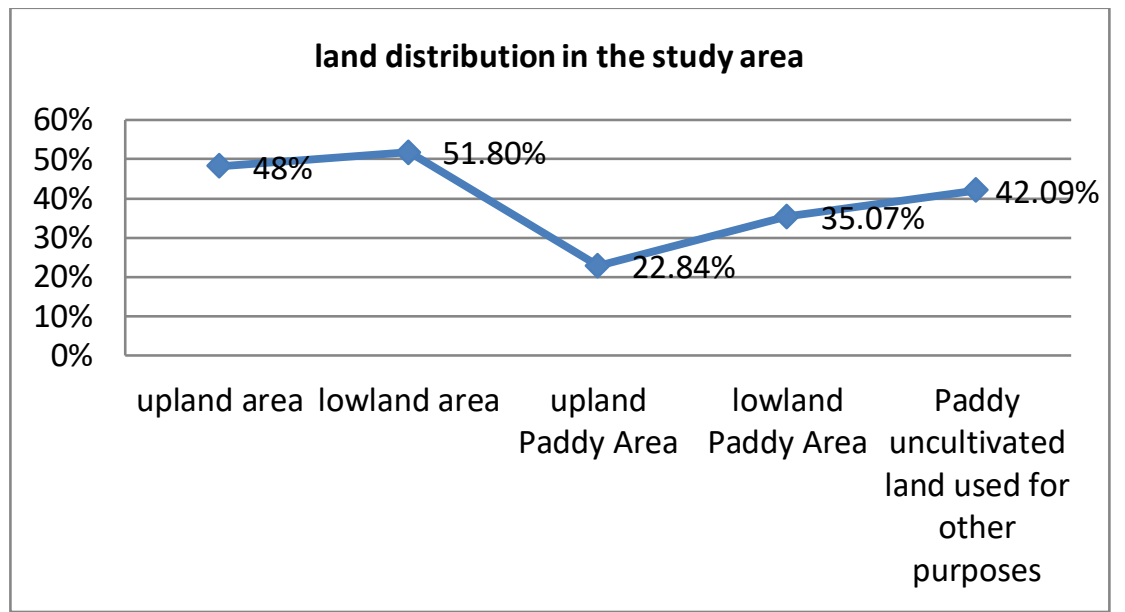

\subsubsection{Education status}

The literacy rate of the respondents was found to be $70 \%$ and among them only $20 \%$ have studied above SLC or above and $50 \%$ of the population has studied below SLC.

Table: Education status of different ethnic groups in the study area

\begin{tabular}{|c|c|c|c|c|c|}
\hline \multirow{2}{*}{$\begin{array}{l}\text { Education } \\
\text { status }\end{array}$} & \multicolumn{4}{|l|}{ Ethnicity } & \multirow[t]{2}{*}{ Total $(\%)$} \\
\hline & Janajati(\%) & Dalit (\%) & Bramhin/Chettri & $\begin{array}{l}\text { Other caste } \\
(\%)\end{array}$ & \\
\hline Illiterate & 7.5 & 5.0 & 12.5 & 5.0 & 30 \\
\hline Up to SLC & 7.5 & 10 & 30 & 2.5 & 50 \\
\hline Above SLC & 5.0 & 0 & 15 & 0 & 20 \\
\hline $\begin{array}{l}\% \text { of total } \\
\text { population }\end{array}$ & 20 & 15 & 57.5 & 7.5 & 100 \\
\hline
\end{tabular}

\subsubsection{Occupation}

Agriculture is still the major occupation and income source of the study area where $42.5 \%$ of the population is involved in agriculture followed by government service $27.5 \%$ and business $15 \%$.

$10 \%$ of the people have foreign job, $2.5 \%$ have private job and remaining $2.5 \%$ population was involved in other income generating activities. 
International Journal of Social Science and Economic Research

ISSN: $2455-8834$

Volume:05, Issue:08 "August 2020"

\begin{tabular}{|c|c|c|c|}
\hline \multicolumn{2}{|c|}{ Demographic characteristics } & Frequency & Percentage $\%$ \\
\hline \multirow[t]{3}{*}{ 1.Gender } & Male & 32 & 80 \\
\hline & Female & 8 & 20 \\
\hline & Total & 40 & 100 \\
\hline \multirow[t]{4}{*}{ 2. Education } & Illiterate & 12 & 30 \\
\hline & Up to SLC & 20 & 50 \\
\hline & above SLC & 8 & 20 \\
\hline & Total & 40 & 100 \\
\hline \multirow[t]{7}{*}{$\begin{array}{l}3 . \\
\text { occupation }\end{array}$} & Agriculture & 17 & 42.5 \\
\hline & Government service & 11 & 27.5 \\
\hline & NGO/PVT job & 1 & 2.5 \\
\hline & Business & 6 & 15 \\
\hline & Foreign job & 4 & 10 \\
\hline & Others & 1 & 2.5 \\
\hline & Total & 40 & 100 \\
\hline \multirow[t]{5}{*}{ 4. Ethnicity } & Janajati & 8 & 20 \\
\hline & Dalit & 6 & 15 \\
\hline & Bramhin/chettri & 23 & 57.5 \\
\hline & Others & 3 & 7.5 \\
\hline & Total & 40 & 100 \\
\hline
\end{tabular}


International Journal of Social Science and Economic Research

ISSN: 2455-8834

Volume:05, Issue:08 "August 2020"

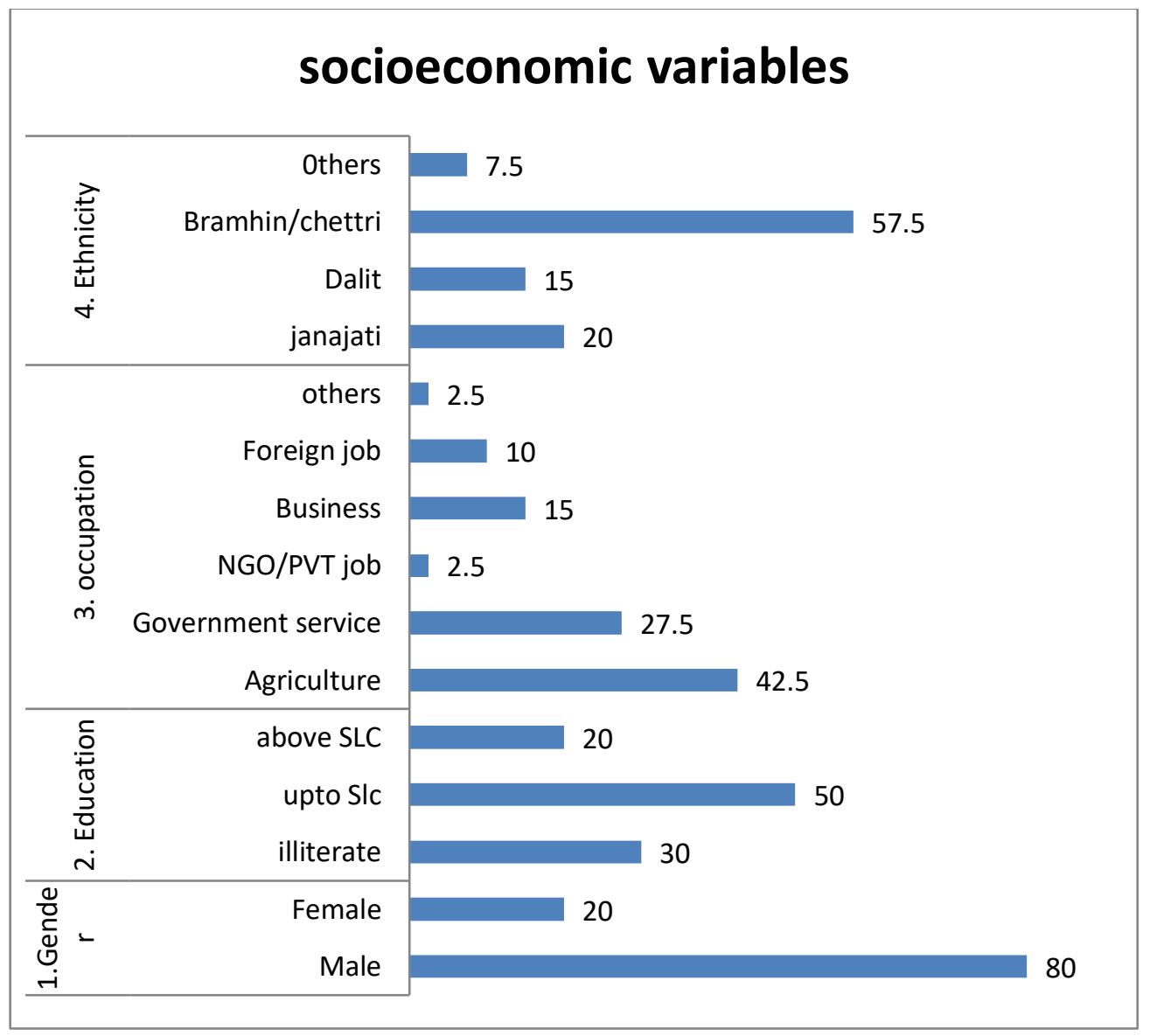

\subsection{Economic analysis}

\begin{tabular}{|l|l|l|l|l|l|l|l|l|}
\hline & $\begin{array}{l}\text { Sukhkh } \\
\text { a2 }\end{array}$ & Sukhkha3 & Sukhkha4 & Sukhkha5 & Sukhkha6 & Local & $\begin{array}{l}\text { Other } \\
\text { improved }\end{array}$ & $\begin{array}{l}\text { Hybrid } \\
\text { varieties }\end{array}$ \\
\hline Seed rate & 2.7 & 1.75 & 2.3 & 2.84 & 4.5 & 4.75 & 3.4 & 4.0 \\
\hline \begin{tabular}{l} 
Seed cost \\
\hline $\begin{array}{l}\text { Total wage } \\
\text { expenses }\end{array}$
\end{tabular} & 7413 & 7556 & 8125 & 8883 & 6987 & 7846 & 7591 & 8288 \\
\hline
\end{tabular}


International Journal of Social Science and Economic Research

ISSN: 2455-8834

Volume:05, Issue:08 "August 2020"

\begin{tabular}{|l|l|l|l|l|l|l|l|l|}
\hline $\begin{array}{l}\text { Total } \\
\text { fertilizer cost }\end{array}$ & 845 & 650 & 655 & 723 & 755 & 735.5 & 760 & 733 \\
\hline $\begin{array}{l}\text { Pesticide } \\
\text { cost }\end{array}$ & 22 & 15 & 12 & 20 & 55 & 25 & 13 & 33 \\
\hline Fixed cost & 430 & 360 & 450 & 467 & 300 & 435 & 455 & 374 \\
\hline $\begin{array}{l}\text { Total cost of } \\
\text { production }\end{array}$ & 8906 & 8971 & 9442 & 10360 & 8452 & 9284. & 9054 & 9868 \\
\hline $\begin{array}{l}\text { Total } \\
\text { revenue }\end{array}$ & 10375.5 & 11121 & 10435 & 11433 & 9825 & 9045 & 11340 & 11026.5 \\
\hline B: C Ratio & 1.157 & 1.236 & 1.105 & 1.103 & 1.162 & .974 & 1.25 & 1.1174 \\
\hline Gross margin & 1899.5 & 2510 & 1443 & 1540 & 1673 & 195.5 & 2741 & 1532.5 \\
\hline $\begin{array}{l}\text { Productivity } \\
\text { in ton/ha }\end{array}$ & 4.21 & 4.53 & 4.15 & 4.75 & 3.75 & 3.68 & 4.73 & 4.55 \\
\hline
\end{tabular}


International Journal of Social Science and Economic Research

3.2.1 Cost of production and revenue analysis:
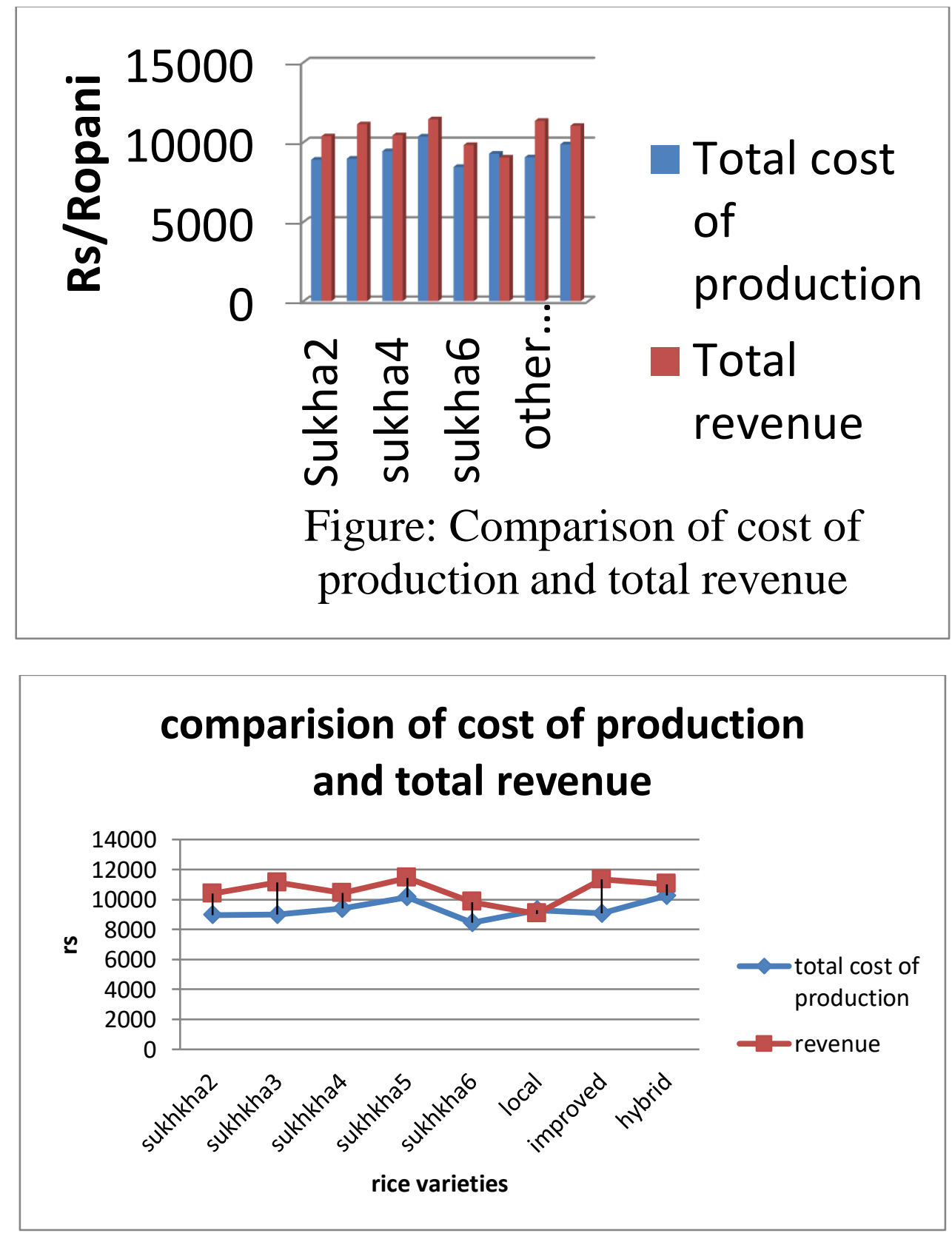

Total cost of production (fixed + variable cost) per Ropani for sukhkha2, sukhkha3, sukhkha4, sukhkha5, sukhkha6, local, other improved and hybrid rice varieties were NRs 8906, 8971, 9442, 10360, 8452, 9284.5, 9054 and 9868 respectively. 


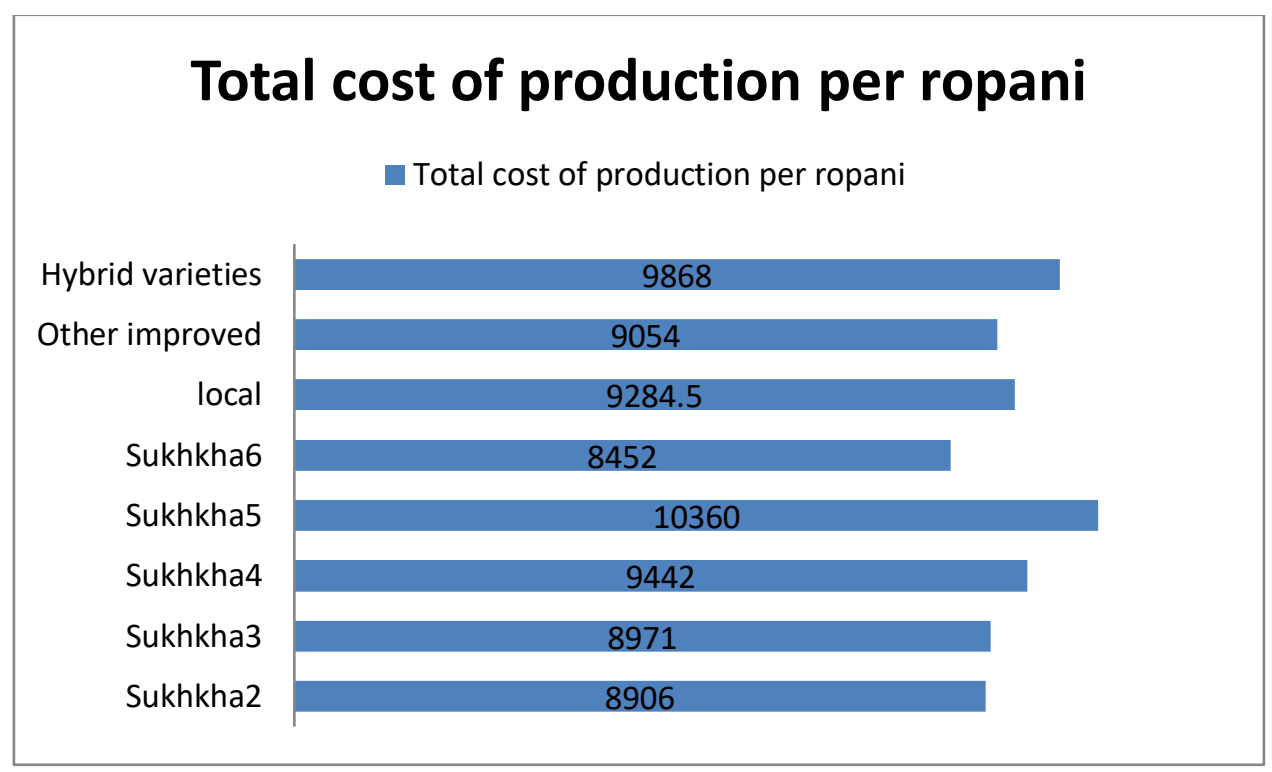

\subsubsection{Total wage expenses comparison}

Maximum cost of production was observed in sukhkha5 due to higher amount of wage expenses which was $13.37 \%$ more than the average wage expenses for all rice varieties (i.e. Rs $7836 /$ Ropani). Hybrid rice varieties ranks second regarding higher cost of production due slightly higher seed cost and more wage expense. Similarly, the wage expense for hybrid variety was $5.8 \%$ more than the average wage expenses for all paddy varieties.

Farmers with higher cost of production can get higher return from their crop (Khan et al., 2009).

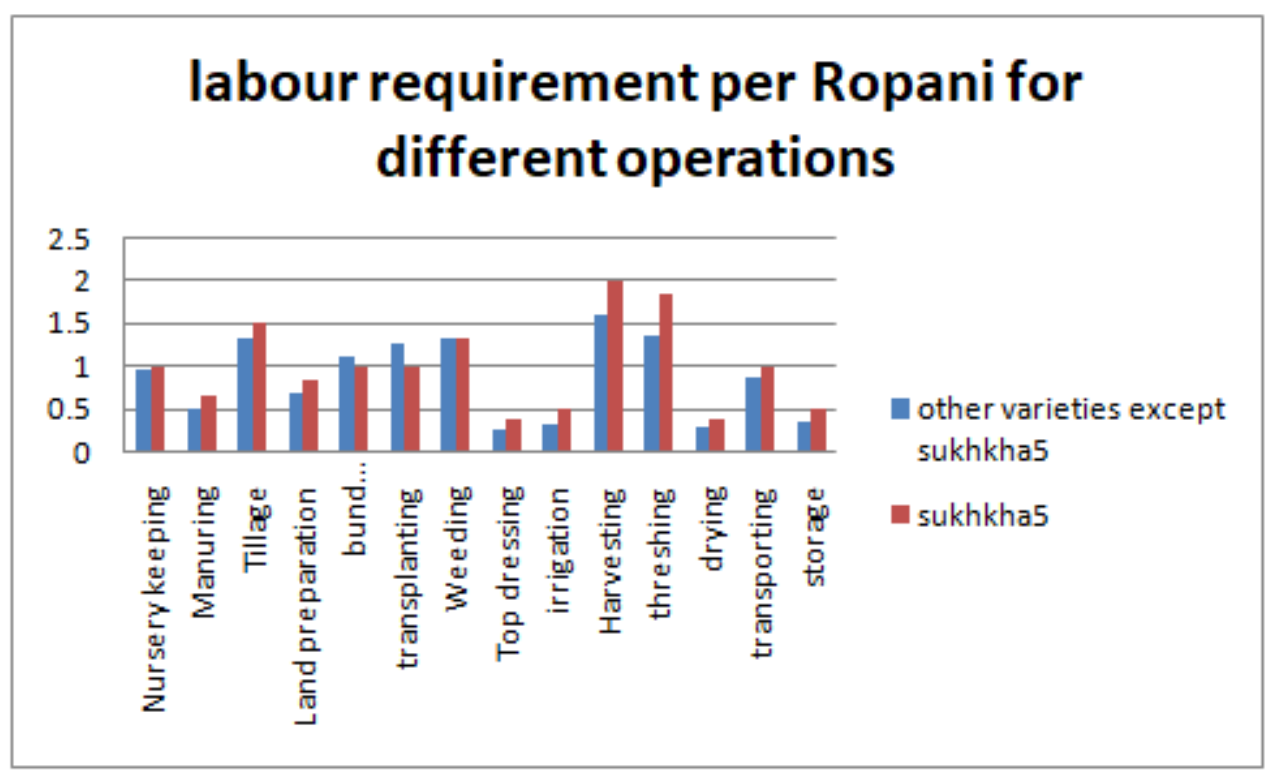


More number of labor were required for sukhkha5 than other varieties in operations like Nursery keeping, manuring, Tillage, Land preparation, Weeding, top dressing, irrigation, harvesting, threshing, drying, transporting and storage. This is because $91.67 \%$ of total land holding of the sukhkha5 growing farmers lies in upland/hills.

Similarly, other cost was also more in case of sukhkha5. Farmers with higher cost of production can get higher return from their crop (Khan et al., 2009).

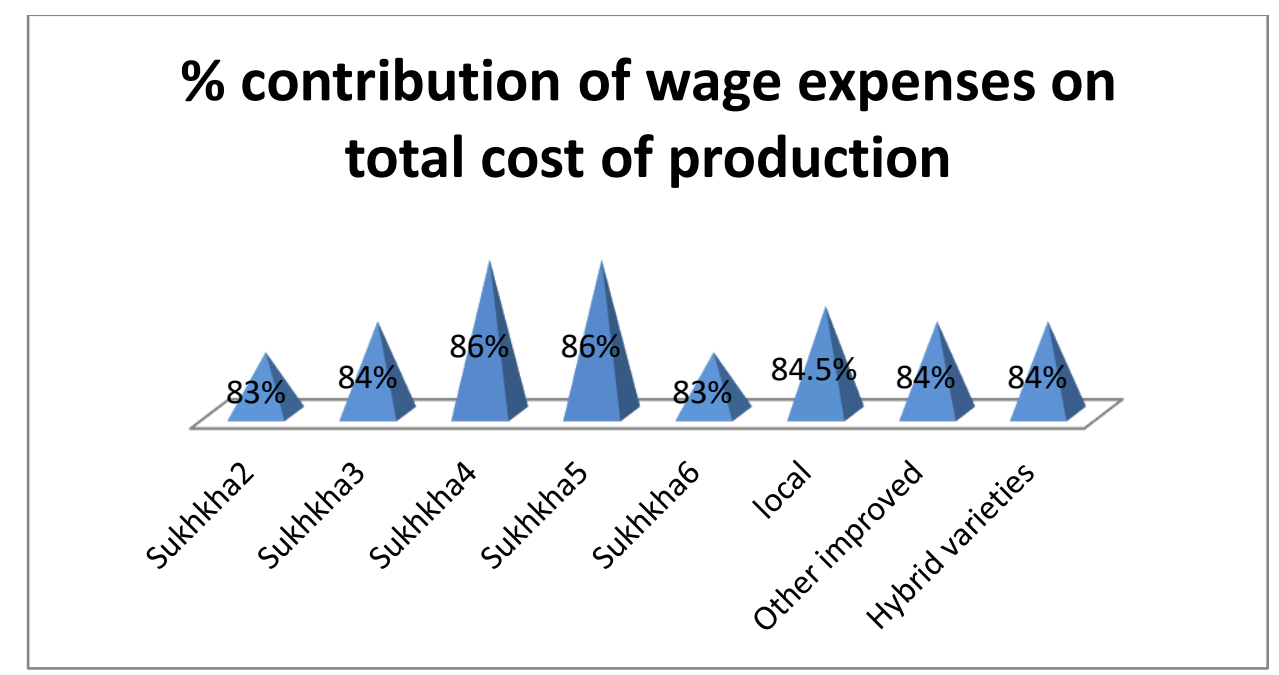

\subsubsection{Seed cost analysis:}

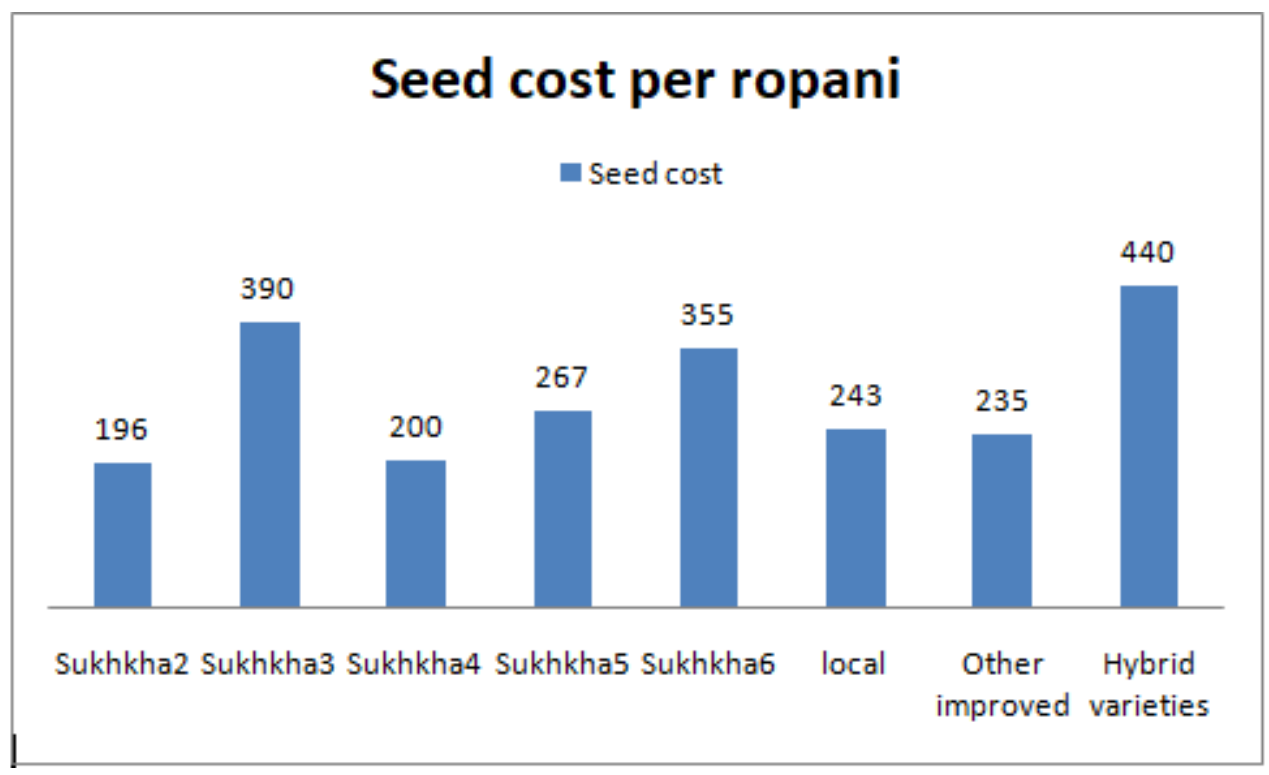


The average seed cost of hybrid rice was Rs 440 per ropani but the average seed cost of other varieties was Rs 270/Ropani. Minimum seed cost was found to be Rs 196/Ropani of Sukhkha2.

\subsubsection{Total Revenue analysis:}

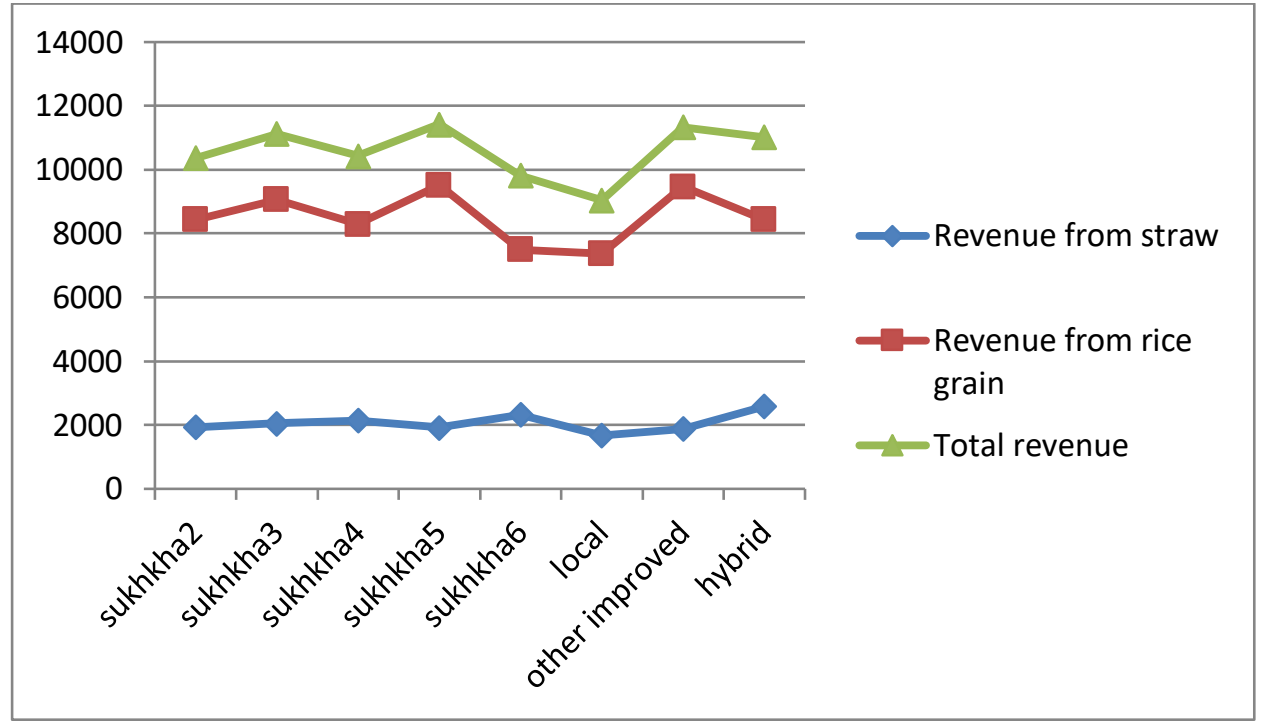

From a Ropani of land, total amount of revenue obtained from Sukhkha2, sukhkha3, sukhkha4, local, improved and hybrid variety was NRs 10375.5, 11121, 10435, 11433, 9825, 9045, 11340 and 11026.5 respectively. Maximum revenue was obtained from Sukhkha5 followed by other improved and hybrid varieties. Minimum revenue was obtained from sukhkha6 and local varieties because the share of income from grains was minimum in these 2 varieties which can be clearly understood from the diagram below: 


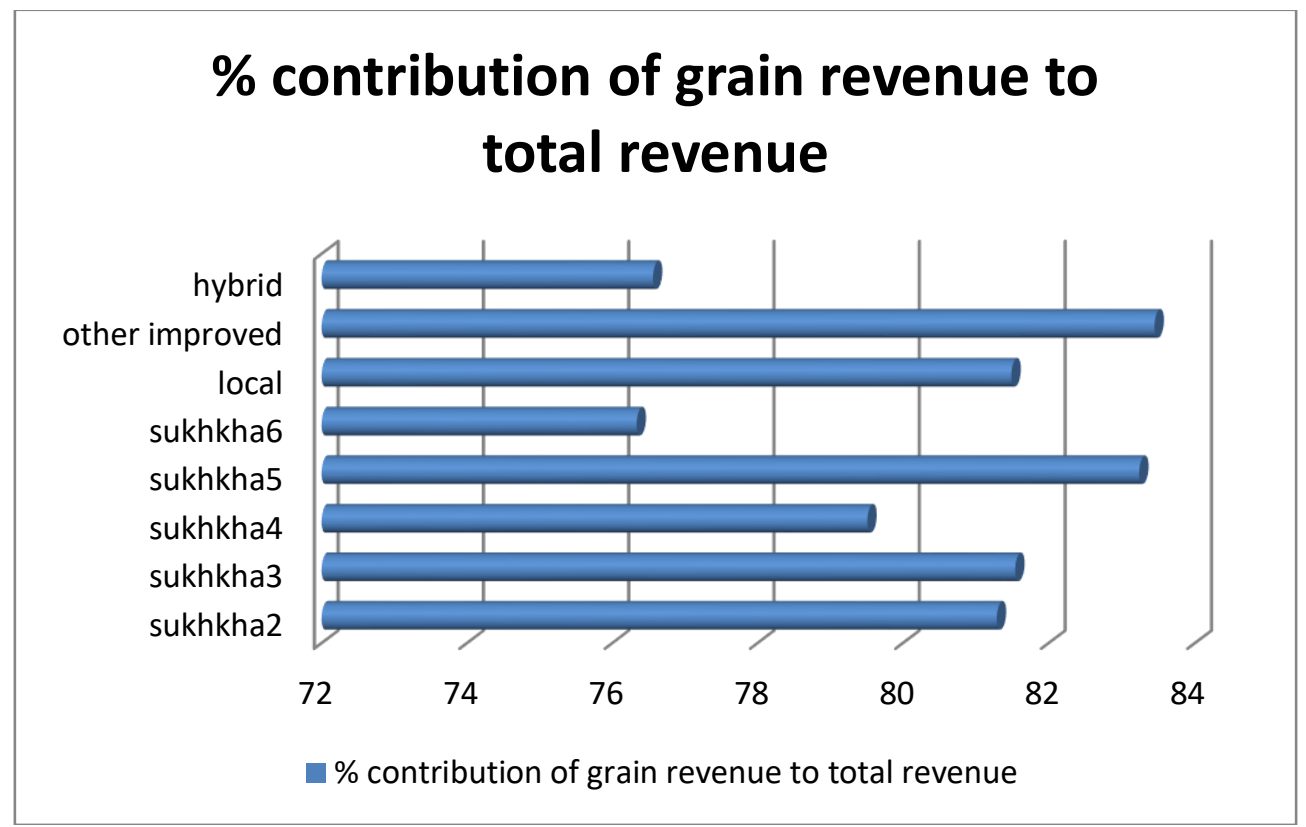

About $83 \%$ of total revenue from sukhkha5 and other improved varieties was accounted from grain whereas the share of grain to total revenue was minimum in sukhkha6 and hybrid varieties.

\subsubsection{Profit and Gross Margin Analysis:}

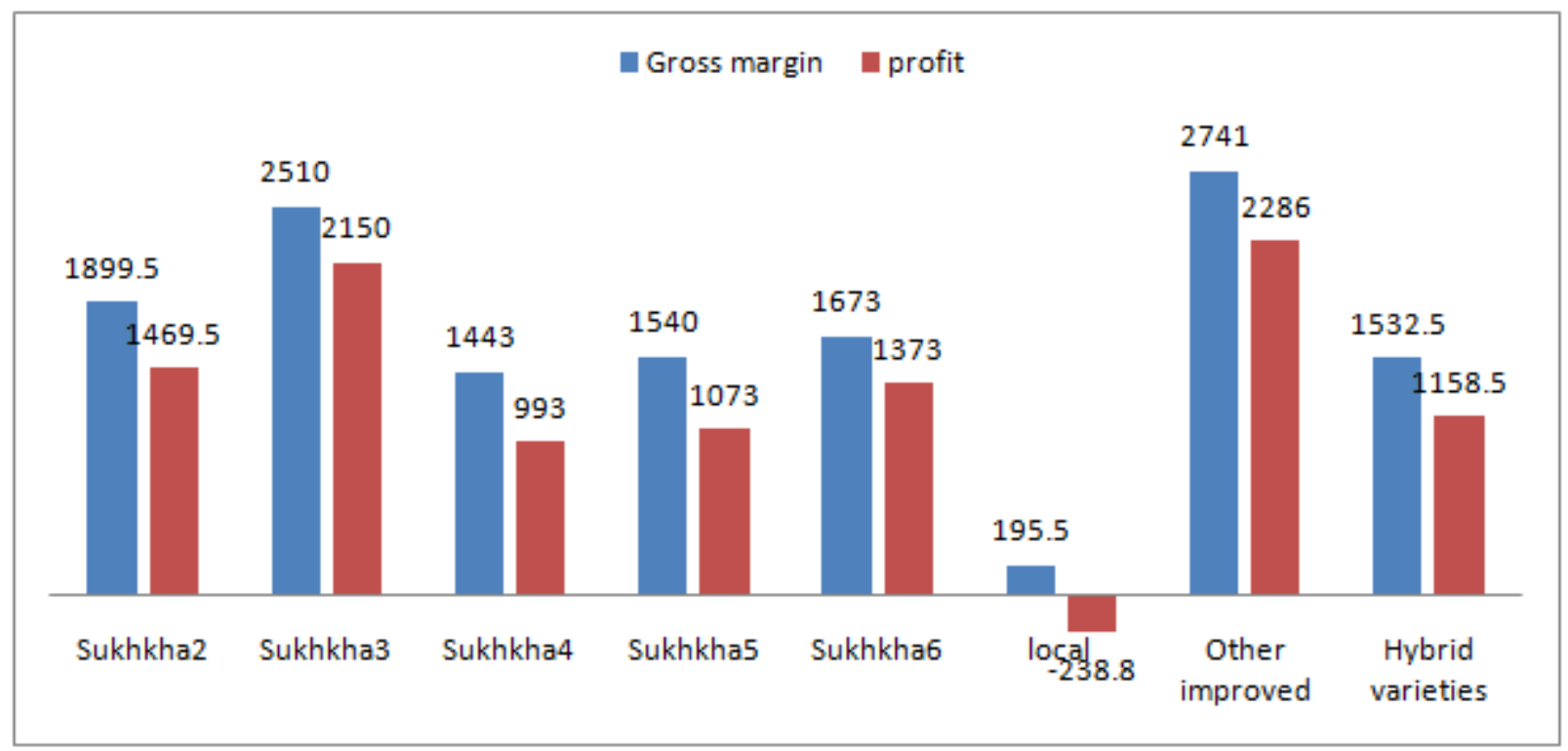

Maximum profit and gross margin was observed in other improved varieties followed by Sukhkha3. Local varieties were economically unviable to cultivate. 


\subsection{Preference while eating:}

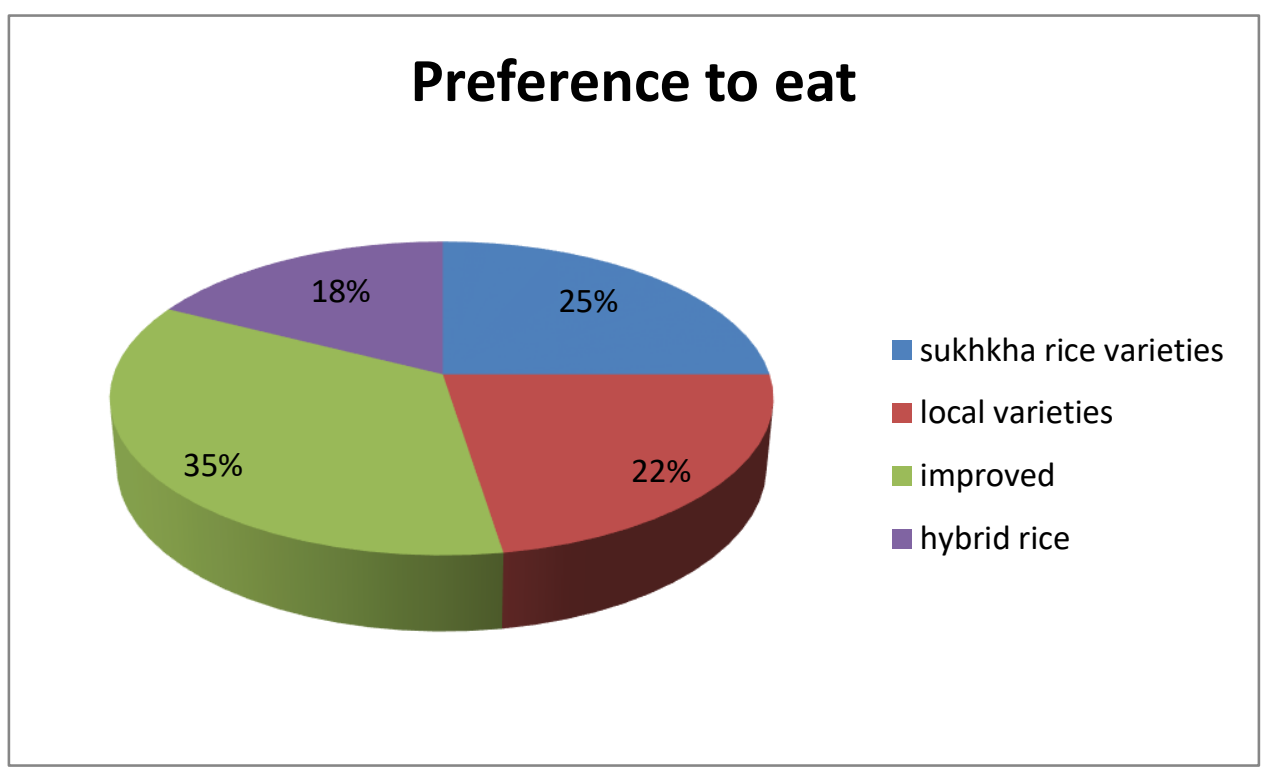

$35 \%$ of the respondents preferred other improved varieties to eat because improved varieties are fine to eat and they are nutritious too but local varieties are coarse in nature.

\subsection{Seed rate comparison:}

Farmers used $4.75 \mathrm{~kg} /$ Ropani of seed for local varieties like Anadi, Mansuli, Sano dale etc. lowest amount of seed per Ropani was used in Sukhkha3. Lack of knowledge regarding seed requirement and method of cultivation was observed.

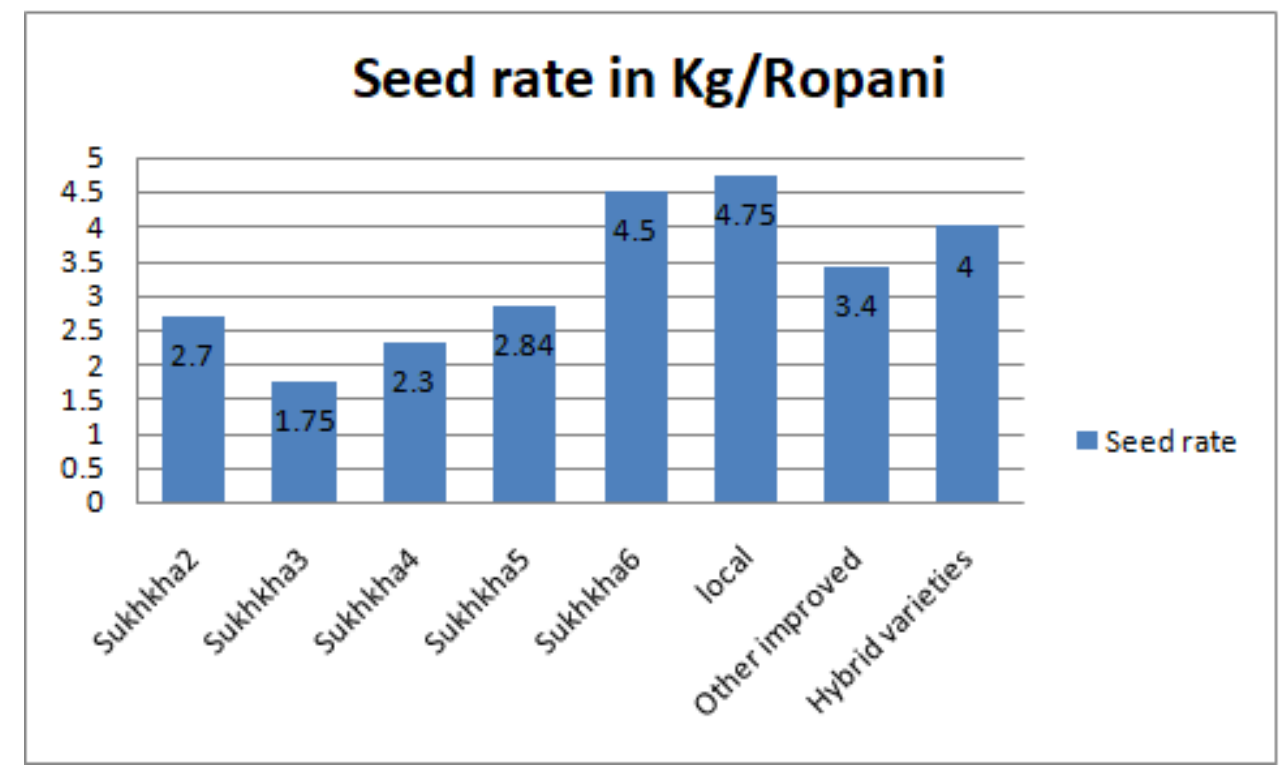




\subsection{B:C ratio and productivity analysis:}

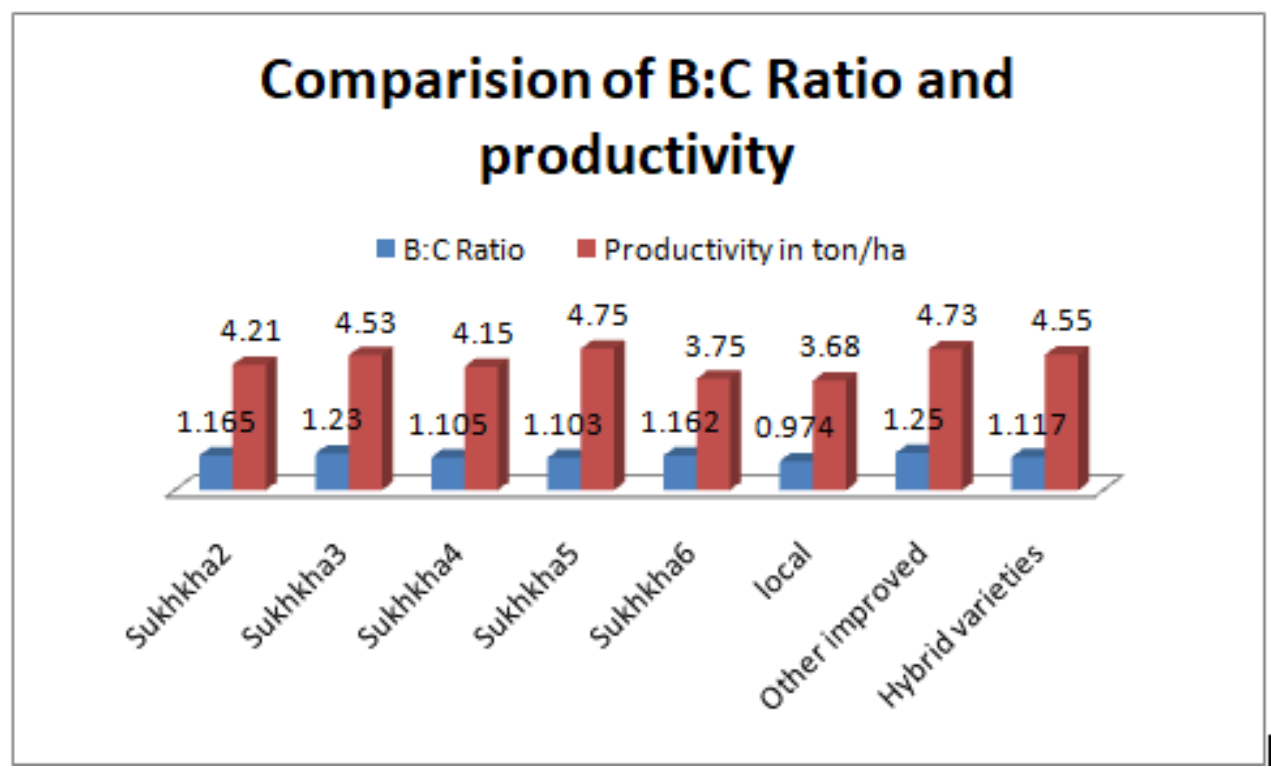

Maximum B: C Ratio was observed in other improved varieties followed by sukhkha3 variety. Sukhkha5 being a drought tolerant variety, has productivity of 4.75 and minimum productivity was observed in local varieties like Sano dalle, Mansuli and AnadiDhan.

Under drought condition, drought tolerant varieties in Nepal have a good mean yield of 3.5 to 4.2 tons per ha (Yadav, 2014).

Similar result was also found in a research conducted by Nwaobiala, C.U. \&Adesope, Olufemi.(2013) in Ebonyi State, South east Nigeria, Upland rice farmers had a Benefit Cost Ratio of N1.55 (1.56USD). The net profit from Swamp/lowland rice cultivation was 132,090.00 NGN (852.19USD) and a Benefit Cost Ratio of 1.75 NGN (1.75USD).

\section{CONCLUSION}

* $80 \%$ of the household heads were Male, Agriculture was still the major occupation and majority of the respondents were Bramhin/ Chettri

* Maximum cost was incurred in Sukha5, highest revenue was also obtained from the variety itself.

* Sukha6 is the most labor efficient variety but has lowest productivity among other drought tolerant varieties.

* Other improved varieties followed by Sukha3 provide maximum income per unit cost.

* Local varieties are economically unviable to cultivate.

* Improved varieties are mostly preferred to eat. 


\section{International Journal of Social Science and Economic Research}

ISSN: 2455-8834

Volume:05, Issue:08 "August 2020"

\section{RECOMMENDATIONS}

The study makes following strategic recommendations for rapid dissemination of droughttolerant rice varieties in the study area:

1. Popularization of drought tolerant rice varieties through extension demonstration and awareness creation employing participatory research and extension.

2. Promotion of appropriate size of mini-kits to small farmers in stress-prone domains with input support and subsidies.

3. Providing awareness regarding the difference in cultivation practices of upland and lowland rice varieties.

4. Training and capacity building of seed actors in seed production and marketing.

5. Seed production and marketing of drought tolerant varieties by multiple channels and sources.

6. Targeting of seed and input subsidies with new drought tolerant rice varieties and effective implementation of existing seed policy and regulation.

7. Identification and mapping of target drought-prone domains and target groups for further dissemination.

8. Targeting fast track variety development and release for specific drought-prone domains.

5. Development of effective seed-networks of relevant actors for drought tolerant varieties

9. Timely delivery of market information to upland rice farmers as to enable the sale their products at appropriate price.

\section{References}

MoAC. 2005. Statistical information on Nepalese agriculture: Time series information (19912004). Ministry of Agriculture and Cooperative, Kathmandu, Nepal.

Yuan Longping. 2004. Hybrid Rice Technology for Food Security in the World TheWorld Food

Prize

International Symposium

IRRI. International Rice Research Institute. http://www.irri.org 
International Journal of Social Science and Economic Research

ISSN: 2455-8834

Volume:05, Issue:08 "August 2020"

Iqbal, M., M. Hanif and A.R. Bajwa, 1987. Role of Blue Green Algae in Paddy Production. Publication No. 163, Mona Reclamation

Experimental Project WAPDA, Bhalwal-Pakistan

Junejo, M.R., M.M. Alam, N. Ali and A. Ghaffar, 2001. Impact of VariousInputs on Paddy Yield. Publication No. 25, Mona Reclamation

Experimental Project, WAPDA, Bhalwal-Pakistan

Kahlown, M.A. and M. Iqbal, 1997. Impact of Waterlogging On MajorCrop Yields. Fordwah Eastern Sadiqia (South) Irrigation and

Drainage Project. Publication No.227, Mona Reclamation Experimental Project, WAPDA, Bhalwal-Pakistan

Raza, Z.I., M. Ashraf and M.M. Alam, 2001. Evaluation of Resource Conservation Technologies in Rice-Wheat System. Publication No.

249, Mona Reclamation Experimental Project, WAPDA, Bhalwal- Pakistan

Ali, N., A. Ghaffar and A. Ali, 1994. Wheat Yield Response to Farm Inputs. Mona Reclamation Experimental Project WAPDA, Bhalwal.

Publication No.211

Narasimham ,(2003), Cost and returns of paddy in Yanam Region of Union Territory of Pondicherry. TheAndhraAgril. J., 50(1): 131135.

Chaudhry, M.R., and M.S. Rafique, 1990. Comparative Efficiency of Sulphuric Acid and Gypsum Alone and in Combination with

Farmyard Manure on Reclamation and Crop Production. MonaReclamation Experimental Project WAPDA, Bhalwal. Publication

No.179

Pro Public. (2002), Economic Liberalization and Open Market Policy: Livelihood and Rights of Farmers Brie $\square$ ng paper, Kathmandu, Forum for Public Right, p.1

Television Trust for Environment (2004), Judi 572- Nepal. Hands on-Paddy-rice Chronicles Series 5 . 
International Journal of Social Science and Economic Research

ISSN: 2455-8834

Volume:05, Issue:08 "August 2020"

R. Adhikari, 2011. Economics of organic rice production. The journal of agriculture and environment vol:12. Available on: www.nepjol.info/index.php/AEJ/article/download/7 $\underline{569 / 6152}$,

mackill DJ, Collard BCY, Neeraja CN, Rodriguez RM, Heuer S, Ismail AM. QTLs in rice breeding: examples for abiotic stresses. In: Brar DS, Mackill DJ, Hardy B, editors. Rice genetics 5: Proceedings of the International Rice Genetics Symposium. Manila: International Rice Research Institute; 2006. pp. 155-167.

Harlan JR (1975) Our vanishing genetic resources. Science 188:618-621.

Bellon MR (2008) Do we need crop landraces for the future?Realizing the global option value of in situ conservation.In: Kontoleon A, Pascual U and Smale M (eds) Agrobio-diversity and Economic Development. USA: Routledge.

Jarvis D and Hodgkin T (2000) Farmer decision making andgenetic diversity: linking multidisciplinary research toimplementation on-farm. In: Brush S (ed.) Genes in theField: On-farm Conservation of Crop Diversity. Boca Raton,FL: IPGRI, IDRC, and Lewis Publication, pp. 261278.

Zeven AC (1998) Landraces: a review of definitions and classi-fications. Euphytica 104: 127139.

Chengappa, P.G., AldasJanalah and Gowda, MV.S (2003) Profitability of hybrid rice cultivation evidence from Karnataka Economic and political weekly; 38(25): 2531 - 2534.

Faquir, S.B. 1981. Relationship between farm size and economic efficiency - An analysis of farm level data from Haryana (India). Canadian Journal of Agricultural Economics. 29: 317-326.

Nirmala, B. 2009. Factor productivity of rice cultivation in Karnataka. Environment and Ecology. 27: 1110-1112.

Fried H.O, Lovell C. A. K. \& Schmidt, S.S. (2008), Efficiency and Productivity, In H. O. Fried. A. Knox Lovell and S. S. Schmidt 80 (eds.), the measurement of productive Efficiency and productivity Change (pp. 3-91). New York: Oxford University Press. Doi: Oxford Scholarship Online.

Kumbhakar, S.C. \&.Lovell, C.A.K. (2000), Stochastic Frontier Analysis, Cambridge, UK: Cambridge University Press.

Johl, S.S and T.R Kapoor.2016. Fundamentals of farm business management. Ludhiana, Kalyani publishers, 83-86p. 
International Journal of Social Science and Economic Research

ISSN: 2455-8834

Volume:05, Issue:08 "August 2020"

Gumma, M. K., D.Gauchan, A. Nelson, S. Pandey and A.Rala. 2011. Temporal changes in ricegrowing area and their impact on livelihood over a decade: A case study of Nepal. Agriculture, Ecosystems \& Environment, 142 (3-4), 382-392.

PACT. 2012.Value Chain Development Plan for Cereal Seed. Project on Agricultural Commercialization and Trade, Ministry of Agricultural Development, Kathmandu, Nepal. 